\title{
Fluorometric Quantitative Analysis of Al(III) Ion Using 5-Methoxy-2-phenyliminomethylphenol
}

\author{
Sun Deuk Kim and Hye Won Lee \\ Department of Chemistry, Daegt Lniversity, Gyeongsan 712-714, Korea. *E-mail: sdkâdaegu.ac.kr \\ Received November 14. 2008, Accepted March 11. 2009
}

\begin{abstract}
A novel Schiff base ligand ( $\mathrm{N}$, O system) 5-methoxy -2-phenyliminomethylphenol ( $5-\mathrm{CH}_{3} \mathrm{O}$-PMP) was synthesized. Using the synthesized ligand as a fluorescent reagent, a fluorometric method was developed for the quantitative analysis of Al(II) ion. The quantitative analysis of Al(II) ion was performed by making the complex compound between $\mathrm{Al}(\mathrm{III})$ ion and $5-\mathrm{CH}_{3} \mathrm{O}-\mathrm{PMP}$ in ethanol-water solution $(85 / 15, \mathrm{v} / \mathrm{v}, \mathrm{pH} 6.2)$. The excitation wavelength $\left(\lambda_{-m}\right)$ of the complex compound was $397 \mathrm{~nm}$ while the emmision wavelength $\left(\lambda_{e m}\right)$ was $498 \mathrm{~nm}$. The quantitative analy sis of $\mathrm{Al}(\mathrm{III})$ ion was carried out by estimating the fluorescence intensity. The various calibration curves were used for the quantitative analy sis in the range of $0.27 \sim 27 \mathrm{ng} / \mathrm{mL}$ Al(III) ion concentrations. The detection limit was $0.027 \mathrm{ng} / \mathrm{mLL}$. Using the fluorometric method developed in this study, satisfying results were obtained from various samples such as tap water, hot spring water, river water, sea water and waste water, which contained considerable amounts of interfering ions.
\end{abstract}

Key Wonds: Fluorescence spectra. Schiff base ligand. Al(III) Analy sis in natural water

\section{Introduction}

Toxic Al(II) ion can exist in natural water and ground water. In tap water. a trace of $\mathrm{Al}(\mathrm{II})$ ion can also be present due to poly aluminium hydroxychloride or aluminum sulfate which are used as cohesive agents. $\mathrm{Al}(\mathrm{II})$ ion. which can be extracted from teapot ${ }^{3}$ or kitchen utensils. ${ }^{2}$ is harmful to the human body. Thus. development of quantitative analysis for $\mathrm{Al}(\mathrm{II})$ ion is of great interest.

There are many quantitative analytical methods to detect $\mathrm{Al}(\mathrm{II})$ ion in aqueous solution. The atomic absorption spectrophotometric method has been used but it has a low detection limit. ${ }^{3.5}$ Although the fluorometric method is more sensitive than absorption. it has not been widely used except for some organic compounds.

For quantitative analysis of very small amount of $\mathrm{Al}(\mathrm{II})$ ion in aqueous solution ( $\mathrm{ug} / \mathrm{mL} \sim \mathrm{ng} / \mathrm{mL}$ ), various types of Schiff base ligands. which contain nitrogen and oxygen atoms. $^{6-11}$ are used as luminous agents when performing quantitative analysis of a very small amount of $\mathrm{Al}(\mathrm{II})$ ion in aqueous solution (ug/mL $\sim \mathrm{ng} / \mathrm{mL}$ ). Recently. several Schiff base ligands were synthesized and used for fluometric ${ }^{13}$ and electrochemical sensors ${ }^{13,14}$ for $\mathrm{Al}(\mathrm{III})$ ion. However. fluometric quantitative method for $\mathrm{Al}(\mathrm{II})$ ion has rarely been reported.

In this research, a novel Schiff base ligand 5-methoxy-2pheny liminomethylphenol (5- $\left.\mathrm{CH}_{3} \mathrm{O}-\mathrm{PMP}\right)$ was synthesized and used as a luminous agent of $\mathrm{Al}(\mathrm{II})$ ion. Using the new ly synthesized 5- $\mathrm{CH}_{3} \mathrm{O}-\mathrm{PMP}$. the amount of $\mathrm{Al}(\mathrm{II})$ ion in aqueous solution was measured within the limit of 0.27 $\mathrm{ng} / \mathrm{mL}$. The amount of $\mathrm{Al}(\mathrm{II})$ ion in tap water. hot spring water, river water. sea water and waste water was analyzed by a newly developed $\mathrm{Al}(\mathrm{II})$ ion fluorometric method and compared with the previously reported atomic absorption spectrophotometric method.

\section{Experimental}

Reagents and Apparatus. 2-Hydroxy-4-methosybenzaldehy'de, aniline and other metal salts used in this experiment were purchased from Sigma-Aldrich (Missouri, USA, purum grade). Organic solvents such as ethanol. methanol and acid/ base agents purchased from Fluka (Buchs. Switzerland punum grade) were used without further purification. IR spectrum was obtained through Shimadzu IR 440 (Shmadzu. Japan). Fluorescence spectrum was measured with Jasco FP-6300 (Jasco. Japan). ${ }^{\mathrm{H}} \mathrm{H}-\mathrm{NMR}$ and ${ }^{12} \mathrm{C}-\mathrm{NMR}$ spectra were obtained by Varian Mercury 300 NMR (Varian. USA). C.H.N analy sis was performed by Valio EL Analyzer (Elementar, Germany). $\mathrm{pH}$ was measured by Metrohm $692 \mathrm{pH}$ Meter(Metrohm. Swiss). Distilled water used in this experiment was obtained from Milli-Q plus Hyper-pure distilled water maker(Millipore. USA).

Composition of Agent. To synthesize Schiff base ligand (N. O system), prepare 3 volumetric flasks. In each flask. add 0.02 mole $(1.9 \mathrm{~g})$ of aniline and $200 \mathrm{~nL}$ of ethanol. Place the solution into chemical reactors (with Liebig condenser) and stir the solution for 10 minutes in $60^{\circ} \mathrm{C}$. Pour 0.2 moles of 2-hyddroxy-3-methoxybenzaldehyde (3.04 g). 2-hyddroxy-4methoxybenzaldehyde $(3.04 \mathrm{~g})$ and 2-hỵdroxỵ-5-methoxy-

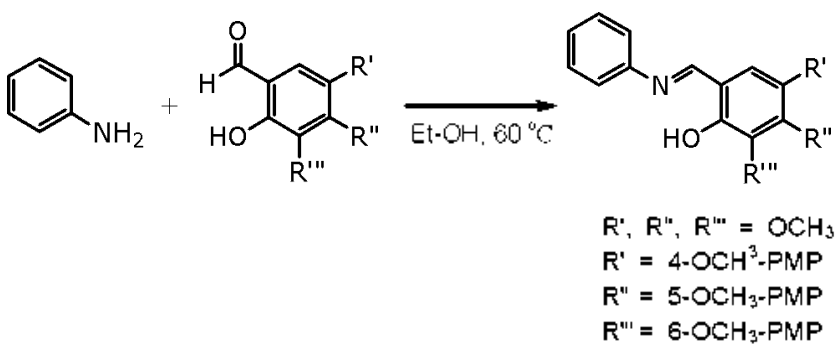

Scheme 
benzaldehyde $(2.6 \mathrm{~mL})$ each into 3 separate reactors by using separated funnels. The solution turns an orange color. Let the orange color solution react for 6 hours and put the solution in a refrigerator for a day. Then yellow crystals appear. Recrystallize the yellow crystal in methanol and dry the crystal in the vacuum desiccator. A synthetic scheme and chemical composition are described.

4-Methoxy-2-phenyliminomethylphenol (4- $\mathrm{CH}_{3} \mathrm{O}-\mathrm{PMP}$ ). Yield: $>68 \%$. Anal. Found: C, 72.91; H, 5.70; N. 6.81: O. 14.58. Calc. for $\mathrm{C}_{14} \mathrm{H}_{13} \mathrm{NO}_{2}$ : C. 73.99: H. 5.77: N. 6.16: O. $14.08 \%$. IR $\left(\mathrm{KBr}, \mathrm{cm}^{-1}\right): 3200(\mathrm{v}, \mathrm{O}-\mathrm{H}) .1610(\mathrm{~V}, \mathrm{C}=\mathrm{N}), 1585$, $1+85(\mathrm{C}=\mathrm{C}), 1670$ (v, C-O). ${ }^{1} \mathrm{H}-\mathrm{NMR}\left(\mathrm{CDCl}_{3}, \mathrm{ppm}\right) 3.8 \mathrm{l}(\mathrm{s}$. $3 \mathrm{H}), 6.90(\mathrm{~d}, J=2.7 .1 \mathrm{H}), 6.99(\mathrm{t}, J=2.4 .1 \mathrm{H}), 7.31(\mathrm{t} . J=6.9$. $5 \mathrm{H}) .7 .42(\mathrm{t}, J=7.8,1 \mathrm{H}), 8.58(\mathrm{~s}, 1 \mathrm{H}) .{ }^{13} \mathrm{C}-\mathrm{NMR}(\mathrm{CDCl})$ ppm) 55.9. 115.3. 118.0. 118.7. 120.4. 121.1. 126.9. 129.4. 152.2. 155.3, 162.3. Mass (EI): m/z: $227\left(\mathrm{M}^{+}\right) .77$ (base). 51 (fragment)

5-Methoxy-2-phenyliminomethylphenol (5- $\left.\mathrm{CH}_{3} \mathrm{O}-\mathrm{PMP}\right)$. Yield: $>65 \%$. Anal. Found: C, 79.12: H. 6. 18: N, 7.01; O. 7.69. Calc. for $\mathrm{C}_{14} \mathrm{H}_{13} \mathrm{NO}: \mathrm{C} .79 .60: \mathrm{H}, 6.20:$ N. 6.63: O. 7.57\%. IR $\left(\mathrm{KBr} . \mathrm{cm}^{-1}\right): 3200(\mathrm{~V}, \mathrm{O}-\mathrm{H}), 1612(\mathrm{~V}, \mathrm{C}=\mathrm{N}) \cdot 1580,1+80(\mathrm{C}=\mathrm{C})$. 1670 (v, C-O). ${ }^{\mathrm{l}} \mathrm{H}-\mathrm{NMR}$ (CDCl. ppm) 3.81 (s. $\left.3 \mathrm{H}\right) .6 .90$ (d. $J=2.7 . \mathrm{lH}) .6 .99(\mathrm{t} . J=2.4 \mathrm{lH}) .7 .3 \mathrm{l}(\mathrm{t} . J=6.9 .5 \mathrm{H}) .7 .42(\mathrm{t}$. $J=7.8,1 \mathrm{H}) .8 .58$ (s. 1H). ${ }^{13} \mathrm{C}-\mathrm{NMR}\left(\mathrm{CDCl}_{3}, \mathrm{ppm}\right) 55.4$. $101.0,117.1,113.0,120.9,126.3,129.3,129.3,133.5,148.3$. 161.4, 163.9, 164.0. Mass (EI): m/z: $227\left(\mathrm{M}^{+}\right) .77$ (base). 51 (fragment)

6-Methoxy-2-phenyliminomethylphenol (6- $\mathrm{CH}_{3} \mathrm{O}-\mathrm{PMP}$ ). Yield: $>75 \%$. Anal. Found: C, 79.12; H, 6.18; N. 7.01: O. 7.69. Calc. for $\mathrm{C}_{1} \mathrm{H}_{13} \mathrm{NO}:$ C. 79.60: H, 6.20: N. 6.63: O. $7.57 \%$. IR (KBr, $\left.\mathrm{cm}^{-1}\right): 3200(\mathrm{v} . \mathrm{O}-\mathrm{H}) .16 \mathrm{l}+(\mathrm{v}, \mathrm{C}=\mathrm{N}), 1585$. $1480(\mathrm{C}=\mathrm{C}) .1670(\mathrm{v}, \mathrm{C}-\mathrm{O}) .{ }^{\mathrm{l}} \mathrm{H}-\mathrm{NMR}\left(\mathrm{CDCl}_{3}, \mathrm{ppm}\right) 3.93$ (s. $3 \mathrm{H}) .6 .88(\mathrm{t} . J=7.8 . \mathrm{lH}) .7 .00(\mathrm{t} J=7.8,1 \mathrm{H}) .7 .28(\mathrm{t} . J=3.0$. $5 \mathrm{H}) .7 .42(\mathrm{t}, J=7.5,1 \mathrm{H}), 8.62(\mathrm{~s}, 1 \mathrm{H}) .{ }^{13} \mathrm{C}-\mathrm{NMR}(\mathrm{CDCl})$ ppm) 56.1, 114.7, 118.5, 119.1, 121.1, 123.7, 123.7, 126.9. 129.4, 148.1, 148.5, 151.4. 162.6. Mass (EI): $\mathrm{m} / \mathrm{z}: 227\left(\mathrm{M}^{+}\right), 93$ (base). 77 (fragment)

Experimental Method A ligand 5- $\mathrm{CH}_{3} \mathrm{O}$-PMP was successfully synthesized. $1.0 \times 10^{\cdot 3} \mathrm{M}$ solution of $\mathrm{AlK}\left(\mathrm{SO}_{4}\right)_{2} \cdot 12 \mathrm{H}_{2} \mathrm{O}$ was used as the $\mathrm{Al}(\mathrm{II})$ ion standard solution and was diluted when necessary. The pH buffer solution of various concentration was prepared from the mixture of acetic acid and salt. Ethanol-water solvent $(85 / 15 . \mathrm{v} / \mathrm{v})$ was used in the preparation of both test solution and buffer solutions.

The test solution was prepared by the following process: 5 $\mathrm{mL}$ of $1.0 \times 10^{-4} \mathrm{M} 5-\mathrm{CH}_{3} \mathrm{O}$-PMP was mixed with $5 \mathrm{~mL}$ of 1.0 $\times 10^{-6} \sim 1.0 \times 10^{-9} \mathrm{M} \mathrm{Al}(\mathrm{II})$ metal solution in a $50 \mathrm{~mL}$ volumetric flask and $5 \mathrm{~mL}$ of $\mathrm{pH} 6.2$ buffer solution was added to the mixture. Then ethanol-water $(85 / 15, \mathrm{v} / \mathrm{v})$ solution was added to the marked line. A calibration curve was drawn using integrated area as well as maximum fluorescence intensity. Emission slit width was set up as 10/20 nm. Al(D) standard solution was made from $\mathrm{AlK}\left(\mathrm{SO}_{4}\right)_{2} \cdot 12 \mathrm{H}_{2} \mathrm{O}$ and its concentration was $1.0 \times 10^{-3} \mathrm{M}$. It was diluted and then used when it was necessary.

A quantitative analy sis of $\mathrm{Al}(\mathrm{II})$ ion was performed by the following process: solutions of known concentrations were prepared and bubbled for 3 minutes by nitrogen gas. Then the solution was placed in water bath at $35^{\circ} \mathrm{C}$ and left for more than 40 minutes in room temperature. The fluorescence intensity measurement was carried out.

The amount of $\mathrm{Al}(\mathrm{I})$ ion in natural water was analyzed using calibration curve and standard addition method. AAS analy sis was also performed as a blank test. An experiment on the interfering ion concentration was performed by the following process: $5 \mathrm{~mL}$ of $1.0 \times 10^{-4} \mathrm{M} 5-\mathrm{CH}_{3} \mathrm{O}$-PMP was mixed with $5 \mathrm{~mL}$ of $1.0 \times 10^{-3} \sim 1.0 \times 10^{-9} \mathrm{M} \mathrm{Al}($ III) metal solution in a $50 \mathrm{~mL}$ volumetric flask and $5 \mathrm{~mL}$ of $\mathrm{pH} 6.2$ buffer solution was added to the mixture. Then ethanol-water $(85 / 15 . \mathrm{v} / \mathrm{y})$ solution was added to the marked line and the fluorescence intensity of the solution was measured. Estimation of the interfering ion concentration was done by the fluorometry(several metal cation and anion solutions were added to a test solution). Tap water and sea water were investigated. The $\mathrm{HNO}_{3}(2 \mathrm{~mL} / \mathrm{L})$ solution was added to the test solution. ${ }^{15}$

\section{Result and Discussion}

Synthesis. Schiff base ligand 4- $\mathrm{CH}_{3} \mathrm{O}-\mathrm{PMP}$. 5- $\mathrm{CH}_{3} \mathrm{O}-\mathrm{PMP}$ and $6-\mathrm{CH}_{3} \mathrm{O}$-PMP were synthesized through the following process; Aniline. 2-hydroxy-3-methoxybenzadehyde, 2-hydroxy-4-methoxy-benzealdehyde. 2-hyddroxy-5-methoxybenzaldehyde were dissolved in methanol and the reaction proceeded at $60^{\circ} \mathrm{C}$. C, H and $\mathrm{N}$ atomic analysis shows composition of each ligand exactly matched the theoretical values. Imine $(-\mathrm{C}=\mathrm{N}-)^{\prime}$ 's IR absorption peak, which is characteristic of $\mathrm{CH}_{2} \mathrm{O}-\mathrm{PMP}$ Schiff base ligands. appeared at $1610-1612 \mathrm{~cm}^{-1}$. Hydrogens attached to the carbon of imine group appeared at 8.58-8.62 ppm in ${ }^{1} \mathrm{H}$ NMR spectrum. In ${ }^{13} \mathrm{C}$ NMR spectrum. carbon atoms of imine group were confirmed at 162.3-164.0 ppm. In GC-mass spectrum, m/z value of 231 peak(molecular ion peak. $\mathrm{M}^{-}$) appeared in all ligands and $\mathrm{m} / \mathrm{z}$ value of 77 peak corresponding to benzene were observed. These results con-

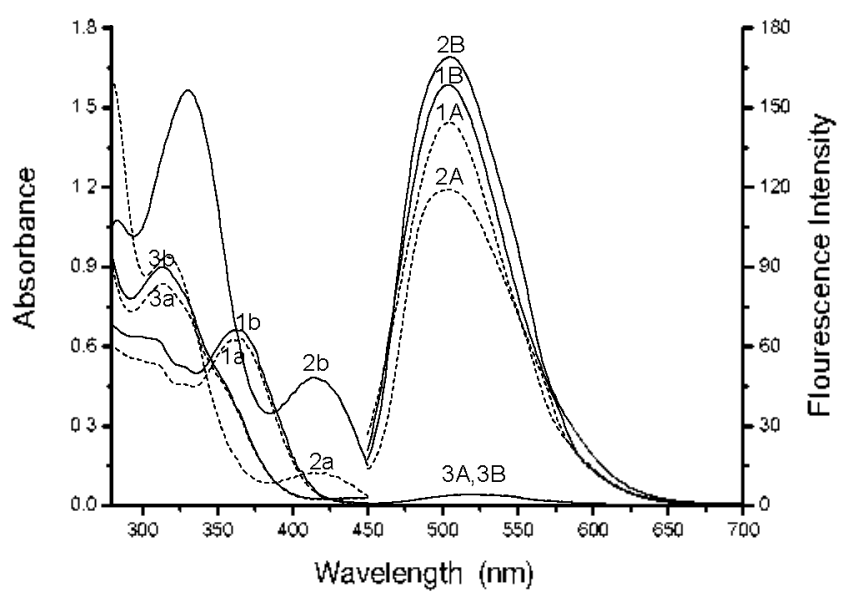

Figure 1. Absorption and fluorescence emission spectra of $\mathrm{CH}_{3} \mathrm{O}$ PMP and its complex with aluminium( II ) ion in [ethenol] $=85 \%$; $\mathrm{pH}=6.2,\left[\mathrm{CH}_{3} \mathrm{O}-\mathrm{PMP}\right]=1.0 \times 10^{-4} \mathrm{M} \cdot\left[\mathrm{Al}^{3+}\right]=1.0 \times 10^{6} \mathrm{M} .(1) \mathrm{la}, \mathrm{lb}$ and $\mathrm{IA}, \mathrm{IB}$ are UV-visible spectrá and fluorescence emission spectra of 4-C $\mathrm{H}_{3} \mathrm{O}-\mathrm{PMP}$ and $\mathrm{Al}$ (II) $-4-\mathrm{CH}_{3} \mathrm{O}-\mathrm{PMP}$ respectively, (2) $2 \mathrm{a}, 2 \mathrm{~b}$ and $2 \mathrm{~A}, 2 \mathrm{~B}$ are UV-visible spectra and fluorescence emission spectra of 5-C $\mathrm{H}_{3} \mathrm{O}-\mathrm{PMP}$ and $\mathrm{Al}(\mathrm{II})-5-\mathrm{CH}_{3} \mathrm{O}-\mathrm{PMP}$ respectively (3) 3a. 3b and $3 \mathrm{~A}, 3 \mathrm{~B}$ are UV-visible spectra and fluorescence emission spectra of $6-\mathrm{CH}_{3} \mathrm{O}-\mathrm{PMP}$ and $\mathrm{Al}(\mathrm{II})-6-\mathrm{CH}_{3} \mathrm{O}$-PMP respectively. 
firmed the synthesis of $4-\mathrm{CH}_{3} \mathrm{O}-\mathrm{PMP}$. 5- $\mathrm{CH}_{3} \mathrm{O}-\mathrm{PMP}$ and 6-C $\mathrm{H}_{3} \mathrm{O}-\mathrm{PMP}$. in which the sites of the methoxy groups are all different. $^{6}$

Fluorescence Spectra In Fig. 1, the UV/Vis absorption spectra of 4-CH $\mathrm{CH}_{3} \mathrm{O}-\mathrm{PMP}$ (la), 5- $\mathrm{CH}_{3} \mathrm{O}-\mathrm{PMP}$ (2a). 6- $\mathrm{CH}_{3} \mathrm{O}$ PMP (3a) are shown as dotted lines. The UV/Vis absorption spectra of $\mathrm{Al}(\mathrm{II})$ complex of $\mathrm{Al}(\mathrm{II})-4-\mathrm{CH}_{3} \mathrm{O}-\mathrm{PMP}$ ( Ib). Al (III)-5- $\mathrm{CH}_{3} \mathrm{O}-\mathrm{PMP}$ (2b). $\mathrm{Al}(\mathrm{II})-6-\mathrm{CH}_{3} \mathrm{O}-\mathrm{PMP}$ (3b) are shown as solid lines. In addition, the fluorescence spectra of ligands (1A, 2A, 3A) and complexes (1B, 2B, 3B) are shown. As shown in Fig. 1, absorption peaks are observed at $313 \mathrm{~mm}$ (6-C $\left.\mathrm{H}_{3} \mathrm{O}-\mathrm{PMP}\right) .366 \mathrm{~nm}$ (4- $\left.\mathrm{CH}_{3} \mathrm{O}-\mathrm{PMP}\right)$ and $+\mathrm{l}+\mathrm{nm}\left(5-\mathrm{CH}_{3} \mathrm{O}-\right.$ $\mathrm{PMP}$ ) respectively. The ligand $5-\mathrm{CH}_{3} \mathrm{O}-\mathrm{PMP}$ exhibits the most red-shifted peak. This is because the conjugation takes place in different ways depending on the position of the aniline double bond and the 4, 5,6 methosy group of the phenol compound. Briefly, the methory group of 5- $\mathrm{CH}_{3} \mathrm{O}$ PMP is located in a better position for conjugation than that of 4- $\mathrm{CH}_{3} \mathrm{O}$-PMP and 6- $\mathrm{CH}_{3} \mathrm{O}$-PMP. The absorption peaks of $5-\mathrm{CH}_{3} \mathrm{O}$-PMP were $330 \mathrm{~mm}$ and $+1+\mathrm{nm}$. The fluorescence emission intensity from 414 nm was larger than that from 330 $\mathrm{nm}$. Therefore, the emission intensity was measured at 498 $\mathrm{nm}\left(\lambda_{\lambda_{\mathrm{j} n \mathrm{n}}}\right)$ using $+14 \mathrm{~nm}$ as an excitation wavelength.

The fluorescence peak positions of ligands $+-\mathrm{CH}_{3} \mathrm{O}-\mathrm{PMP}$. 5- $\mathrm{CH}_{3} \mathrm{O}$-PMP. 6- $\mathrm{CH}_{3} \mathrm{O}$-PMP appear at $504 \mathrm{~nm}, 503 \mathrm{~nm} .517$ Iun respectively. Fluorescence spectra of $\mathrm{Al}(\mathrm{II})$ complex compound $\mathrm{Al}(\mathrm{II})-4-\mathrm{CH}_{3} \mathrm{O}-\mathrm{PMP}, \mathrm{Al}$ (III)-5- $\mathrm{CH}_{3} \mathrm{O}-\mathrm{PMP}$. $\mathrm{Al}$ (II) $-6-\mathrm{CH}_{3} \mathrm{O}-\mathrm{PMP}$ show emission peaks at $499 \mathrm{~nm}, 498 \mathrm{~mm}$ and $518 \mathrm{~nm}$. respectively. The fluorescence intensity increased when $\mathrm{Al}(\mathrm{II})$ is complexed. Especially. the fluorescence intensity of $\mathrm{Al}(\mathrm{II})-5-\mathrm{CH}_{3} \mathrm{O}-\mathrm{PMP}(2 \mathrm{~B})$ complex compound is larger than the corresponding ligand by more than twice and could provide a parameter for quantitative analysis of Al(II) ion. The fluorescence intensities for $\mathrm{Al}$ (III) complexes are in the following order: $\mathrm{Al}$ (III)-5- $\mathrm{CH}_{3} \mathrm{O}-\mathrm{PMP}>\mathrm{Al}(\mathrm{II})-4-\mathrm{CH}_{3} \mathrm{O}-$ $\mathrm{PMP}>\mathrm{Al}(\mathrm{II})-6-\mathrm{CH}_{3} \mathrm{O}-\mathrm{PMP}$. This order agrees with the emission results of $\mathrm{Al}(\mathrm{II})$ complex with Schiff base 2.2-dihydroxyazomethines. $^{16}$

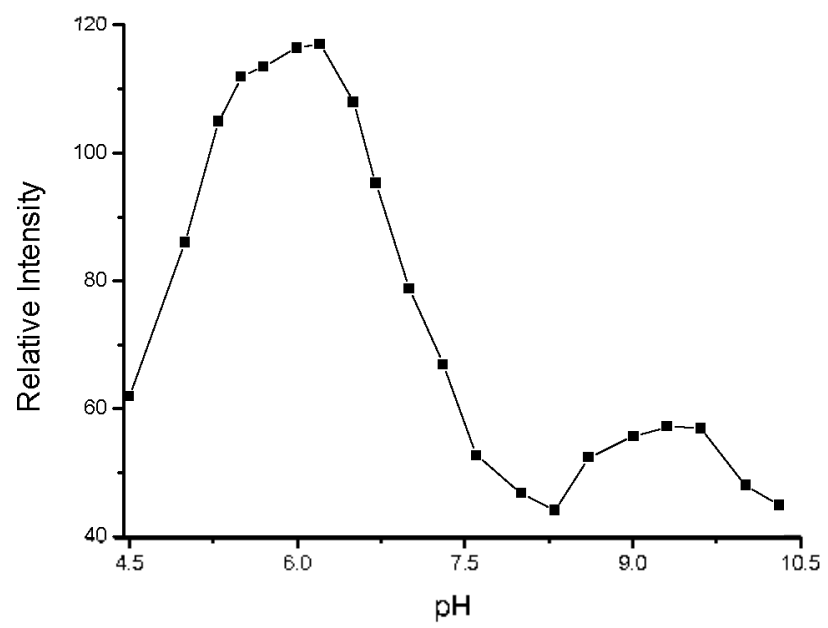

Figure 2. Influence of the apparent $\mathrm{pH}$ on the $\mathrm{Al}(\mathrm{II})-5-\mathrm{OCH}_{3}-\mathrm{PMP}$ comples. The samples were excited at $397 \mathrm{~mm}$ and the fluorescence intensities were recorded at $498 \mathrm{~cm}$. [5-OCH $-P M P]: 1.0 \times 10^{+4} \mathrm{M}$, $\left[\mathrm{Al}^{2-}\right]=1.0 \times 10^{-5} \mathrm{M},[$ Ethanol $]=85 \%, \mathrm{pH}=6.2$.
The Effect of pH and Ethyl Alcohol. Fig. 2 shows the fluorescence intensity change of $\mathrm{Al}(\mathrm{II})$-5- $\mathrm{CH}_{3} \mathrm{O}-\mathrm{PMP}$ complex according to the range of $\mathrm{pH}$. The fluorescence intensity of ligand was subtracted. It is observed that the fluorescence intensity is maximum at $\mathrm{pH} 5.5 \sim 6.2$ range. The intensity drops to the minimum value at $\mathrm{pH} 8.3$. It shows another small peak at $\mathrm{pH} 8.5 \sim 9.7$ range. It is interesting to note that the maximum fluorescence intensity is observed in weak acid condition rather than in basic condition. This is a great advantage to other ligands in which the highest fluorescence intensity is usually observed in basic condition.

In general the proton dissociation of phenol $\mathrm{OH}$ of the Schiff base ligand occurs in strong base. However, the dissociation of phenol $\mathrm{OH}$ proton of $5-\mathrm{OCH}_{3}$-PMP occurs in weak acid and forms a complex with $\mathrm{Al}(\mathrm{II})$ ion. Thus. selectivity to $\mathrm{Al}(\mathrm{III})$ ion becomes higher. If the sample solution is a strong base. protons of all phenols $\mathrm{OH}$ dissociate and become anion. There is no competitive reaction between $\mathrm{Al}(\mathrm{II})$ ion and protons. and the formation of complex with other metal ions becomes much easier. As a result. selectivity decreases. ${ }^{617}$

In order to find out the most adequate alcohol concentration in the analysis of $\mathrm{Al}(\mathrm{II})$ ion concentration of the sample. the volume ratio of ethanol to water was investigated. Below $70 \%$ of ethanol content. fluorescence intensity was low. but the intensity increased for $85 \%$ of ethanol solution. It seents that fluorescence intensity of $\mathrm{Al}$ (II)-5- $\mathrm{CH}_{3} \mathrm{O}$-PMP becomes lower as the alcohol concentration is lower. This is because the solubility of $5-\mathrm{CH}_{3} \mathrm{O}-\mathrm{PMP}$ decreases and hydrolysis can occur easier as the alcohol concentration gets lower. $\mathrm{Al}$ (III) $-5-\mathrm{CH}_{3} \mathrm{O}-\mathrm{PMP}$ complex becomes unstable as the alcohol concentration decreases.

The Effect of Temperature. Fig. 3 shows the fluorescence intensity change with time at several temperatures. The intensity is lighest at $30^{\circ} \mathrm{C}$ and decreased with time. Samples placed in water bath at $30 \sim 40^{\circ} \mathrm{C}$ show low fluorescence intensity in high temperature. As the temperature decreases to $25^{\circ} \mathrm{C}$. the intensity increases and stays constant for 2 hours,



Figure 3. Fluorescence intensity changes according to temperature and time changes. The samples were excited at $397 \mathrm{~nm}$ and the fluorescence intensities were recorded at $498 \mathrm{~nm}$. $\left[5-\mathrm{CH}_{3} \mathrm{O}\right.$-PMP] $=1.0 \times$ $10^{-4}\left[\mathrm{Al}^{3-}\right]=1.0 \times 10^{-8} \mathrm{M},[$ Ethanol $]=85 \%, \mathrm{pH}=6.2$ 


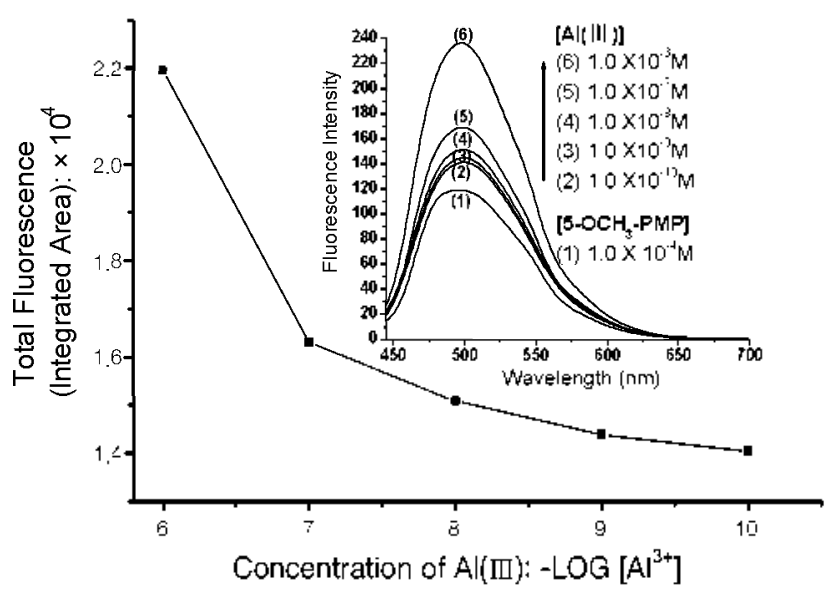

Figure 4 . Changes of both fluorescence integrated area and flnorescence intensity due to concentration change of $5-\mathrm{OCH}_{3}-\mathrm{PMP}$ and Al(III). The samples were excited at $397 \mathrm{~nm}$ and the fluorescence intensities were recorded at $498 \mathrm{~mm}$. [5-C $\left.\mathrm{CH}_{3} \mathrm{O}-\mathrm{PMP}\right]=1.0 \times 10^{-4} \mathrm{M}$, $\left[\mathrm{Al}^{2-}\right]=1.0 \times 10^{-10} \sim 1.0 \times 10^{-6} \mathrm{M},[$ Ethanol $]=85 \%, \mathrm{pH}=6.2$.

but the intensity decreases thereafter. The fluorescence intensity becomes lower as the temperature of solution becomes higher. Quantum efficiency usually decreases as the temperature increases. This is because. as the temperature increases. fluorescence quenching is more effective by collision and nonradiative transition probability increases. By the same reason. as the solvent viscosity decreases. the probability of external conversion also increases and similar results are observed. ${ }^{18.19}$

Calibration Cune and Detection Limit. Fig. 4 shows changes of both integrated area and fluorescence intensity due to concentration changes of 5- $\mathrm{OCH}_{3}-\mathrm{PMP}$ and $\mathrm{Al}(\mathrm{II})$. Here, the concentration of ligand $\left[5-\mathrm{CH}_{3} \mathrm{O}-\mathrm{PMP}\right]$ was fixed at $1.0 \times 10^{-4}$ $\mathrm{M}$ and the concentration of $[\mathrm{Al}(\mathrm{II})]$ ion was varied from $1.0 \times$ $10^{-11} \mathrm{M}$ to $1.0 \times 10^{-6} \mathrm{M}$. Detection limit was estimated to be $0.0027 \mathrm{ng} / \mathrm{mL}$ of $\mathrm{Al}(\mathrm{II})$ which corresponds to $1.0 \times 10^{-5} \mathrm{M}$. The baseline was determined using $5-\mathrm{CH}_{3} \mathrm{O}-\mathrm{PMP}$ ligand at $85 \%$ alcohol and $\mathrm{pH} 6.2$.

Before the nano quantitative analysis of $\mathrm{Al}(\mathrm{II})$ in the aqueous solution, a calibration curve under the pre-described condition was made. The calibration curve showed a linear relationship in the range of $0.27 \sim 27 \mathrm{ng} / \mathrm{mL} \mathrm{Al}$ (II) concentra-
Table 1. Effect of foreign ions on the determination of $27 \mathrm{ng} / \mathrm{mL}$ aluminum. The interfering ion experiments were performed by adding various concentrations of metal ion solutions to $1.0 \times 10^{-4} \mathrm{M}$ 5- $\mathrm{CH}_{3} \mathrm{O}-\mathrm{PMP}$ at $\mathrm{pH} 6.2$.

\begin{tabular}{|c|c|}
\hline Foreign ion species & $\begin{array}{c}\text { Tolerance level } \\
(\mathrm{ng} / \mathrm{mL})\end{array}$ \\
\hline $\begin{array}{l}\mathrm{NH}_{4}^{+}, \mathrm{Ag}\left(\mathrm{I}, \mathrm{Cl}^{-}, \mathrm{I}^{-}, \mathrm{Mn}(\mathrm{I}), \mathrm{Co}(\mathrm{I}),\right. \\
\mathrm{ClO}_{4}^{-}, \mathrm{Br}^{-}, \mathrm{NO}_{3}^{-}, \mathrm{NO}_{2}^{-}\end{array}$ & 150,000 \\
\hline $\begin{array}{l}\mathrm{SCN}^{-}, \mathrm{Na}^{-}, \mathrm{K}^{+}, \mathrm{Ni}(\square), \mathrm{Cd}(\square), \mathrm{Cr}(\mathbb{I}), \\
\mathrm{Ca}(\square), \mathrm{Pb}(\square), \mathrm{Mn}(\square), \mathrm{Co}(\square)\end{array}$ & 100,000 \\
\hline $\operatorname{Zn}(\square)$ & 50,000 \\
\hline $\mathrm{Fe}(\square), \mathrm{Ba}(\square)$ & 30,000 \\
\hline $\operatorname{Mg}(\square), \operatorname{In}(\mathbb{L}), \operatorname{Mo}(\Gamma)$ & 10,000 \\
\hline W(VI), EDTA & 5,000 \\
\hline $\operatorname{sb}(\mathbb{I}), \sin (\Gamma)$ & 2,500 \\
\hline $\mathrm{Cu}(\square), \mathrm{Fe}(\mathrm{II}), \mathrm{Bi}(\mathbb{Z})$, tartaric acid, citric acid & 1,000 \\
\hline $\mathrm{F}^{-}$ & 200 \\
\hline Be( $\square)$, oxalic acid & 150 \\
\hline $\mathrm{Ga}($ II) & 80 \\
\hline
\end{tabular}

tion. Correlation factor of calibration curve was 0.9989 . The sensitivity of the calibration line was considered only for the sample of more than $2.7 \mathrm{ng} / \mathrm{mL}$ of $\mathrm{Al}(\mathrm{II})$ ion concentration where the reproducibility is acceptable. Although the peak shape of the fluorescence spectra in Fig. 4 is not Gaussian the peak area is proportional to the peak height within experimental error in our study.

The Effect of Interfeling Ions. The fluorescence intensity of each complex after adding interfering ions with known concentration into $1.0 \times 10^{-4} \mathrm{M} 5-\mathrm{CH}_{3} \mathrm{O}-\mathrm{PMP}$ and $27 \mathrm{ng} / \mathrm{mL}$ $\mathrm{Al}(\mathrm{II})$ solution was measured. The interfering limit of each ion was set up as $3 \%$ tolerance linit(when $\mathrm{Al}($ III) is $27 \mathrm{ng} / \mathrm{mL}$ ). The result is shown in Table 1 . Be( $\square$ ) ion exhibited interference at the level 7.5 times higher than $\mathrm{Al}(\mathrm{II})$ ion. Unlike In (III) ion $\mathrm{Ga}$ (III) ion of $3 \mathrm{~A}$ family showed interference at the level 3 times higher than $\mathrm{Al}(\mathrm{II})$ ion. $\mathrm{F}^{-}$ion indicated interference at the level 7.5 times lugher than $\mathrm{Al}(\mathbb{I I})$ ion. Other ions did not show significantly high interference level.

In Table 2. our results were compared with the data from the previously published literature in which Schiff base luninous agents was used. Interfering ions whose concentration ranges up to 10 times higher than $\mathrm{Al}(\mathrm{II})$ ion were chosen.

Table 2. Connnon Schiff base reagents for the spectrofluorimetric determination of aluminum.

\begin{tabular}{|c|c|c|c|c|c|}
\hline Reagents & $\begin{array}{l}\text { Detection limit } \\
(11 \mathrm{~g} / 112 \mathrm{~L})\end{array}$ & Solvent & $\mathrm{pH}$ & Interferences & Reference \\
\hline $\begin{array}{l}\text { 4-Chloro-2-phenyliminomethyl-p } \\
\text { henol }\end{array}$ & 0.0027 & $\mathrm{EtOH} \cdot \mathrm{H}_{2} \mathrm{O}$ & 10.5 & 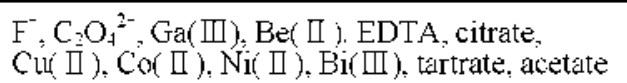 & 6 \\
\hline $5-\mathrm{CH}_{3} \mathrm{O}-\mathrm{PMP}$ & 0.027 & $\mathrm{EtOH} \cdot \mathrm{H}_{2} \mathrm{O}$ & 6.2 & $\mathrm{C}_{2} \mathrm{O}_{4}{ }^{2-}, \mathrm{F}^{-}, \mathrm{Ga}(\mathbb{\Pi}), \mathrm{Be}(\Pi)$ & This work \\
\hline $\begin{array}{l}\text { 2,6-Bis[(O-hydroxy)phenylimino- } \\
\text { methyl]-1-hydroxybenzene }\end{array}$ & 0.1 & $\mathrm{EtOH} \cdot \mathrm{H}_{2} \mathrm{O}$ & 5.0 & Cứ $\square), F e(\mathbb{I})$ & 7 \\
\hline $\begin{array}{l}\text { N-Salicylidene-2-annino-3-hydro- } \\
\text { xytluorene }\end{array}$ & 0.1 & $\mathrm{EtOH} \cdot \mathrm{H}_{2} \mathrm{O}$ & 5.2 & $\mathrm{Cl}^{-}, \mathrm{F}^{-}, \mathrm{PO}_{4}^{3-}, \mathrm{Fe}(\mathbb{I}), \mathrm{Ga}(\mathbb{I})$ & 8 \\
\hline $\begin{array}{l}\text { N. N'Oxaly lbist salicylaldehyde } \\
\text { hydrazone }\end{array}$ & 0.2 & $\mathrm{DMF} \cdot \mathrm{H}_{2} \mathrm{O}$ & 4.7 &  & 9 \\
\hline $\begin{array}{l}\text { 3-Hydroxypyridine-2-aldehyde-2 } \\
\text {-pyridylhydrazone }\end{array}$ & 0.2 & $\mathrm{EtOH} \cdot \mathrm{H}_{2} \mathrm{O}$ & 5.6 & $\begin{array}{l}\mathrm{Co}(\square), \mathrm{Ni}(\square), \mathrm{Pb}(\square), \mathrm{Cu}(\square), \mathrm{Zn}(\square) \\
\mathrm{Fe}(\mathbb{\Pi}), \mathrm{Mn}(\square) \mathrm{F}\end{array}$ & 10 \\
\hline Salicylidene-o-aminophenol & 0.27 & $\mathrm{DMF} \cdot \mathrm{H}_{2} \mathrm{O}$ & 5.8 & $\begin{array}{l}\mathrm{Cr}(\mathrm{I}), \mathrm{Co}(\mathrm{I}), \mathrm{Cu}(\mathrm{II}), \mathrm{Gat}(\mathrm{II}), \mathrm{Fe}(\mathrm{I}), \\
\operatorname{In}(\mathrm{I}), \mathrm{Mo}(\mathrm{V}), \mathrm{Ni}(\mathrm{I}), \mathrm{Sc}(\mathrm{II})\end{array}$ & 11 \\
\hline
\end{tabular}


Table 3. Determination of $\mathrm{Al}(\mathrm{II})$ in water samples from various sources. The water samples were prepared by adding $\mathrm{HNO}_{3}$ and incubated for more than lh between $35^{\circ} \mathrm{C}$ to $45^{\circ} \mathrm{C}$ before fluorescence measurements. Results from the fluorescence spectrometric method are shown, together with the values from standard addition method and atomic absorption spectroscopy(AAS) for the comparison.

\begin{tabular}{lrrr}
\hline \multirow{2}{*}{ Water } & \multicolumn{2}{c}{ Amount found*: ng/mL } \\
\cline { 2 - 4 } & \multicolumn{2}{c}{ Fluorescence spectrometric method } \\
\cline { 2 - 4 } & $\begin{array}{c}\text { Direct calibration } \\
\text { (SE:SD)** }\end{array}$ & $\begin{array}{c}\text { Standard addition method } \\
\text { (SE:SD)** }\end{array}$ \\
\hline Tap water (Gyeongbuk Gunwi) & $157(0.36: 0.89)$ & $159(0.18: 0.45)$ & 160 \\
Tap water (Gyeongbuk Gyeongsan Geumho) & $18(0.22: 0.55)$ & $19(0.18: 0.44)$ & 19 \\
Hot spring water (Gyeongbuk Yeongcheon Sail Onchun) & $18(0.360 .89)$ & $17(0.22: 0.54)$ & 17 \\
Sea water (The East Sea Gyeongbuk Pohang Songdo) & $3,348(1.43: 3.56)$ & $3,395(0.28: 0.70)$ & 3.415 \\
Sea water (The East Sea Gyeongbuk Pohang Bukbu) & $1,215(0.85: 2.13)$ & $1,223(0.41: 1.02)$ & 1,244 \\
River water (Gyeongbuk Pohang Hyeongsant) & $375(0.63: 1.58)$ & $383(0.22: 0.55)$ & 385 \\
Waste water (Gyeongsan waste water treatment area) & $651(1.06: 2.65)$ & $661(0.33: 0.72)$ & 666 \\
\hline
\end{tabular}

* Average of five determinations. ** SE: standard error. SD: standard deviation. *** Data were obtained from Research center for instrumental analysis at Daegu Universitv.

It was found that the detection limit of $\mathrm{Al}(\mathrm{II})$ ion is 0.0027 $0.27 \mathrm{ng} / \mathrm{mL}$ when Schiff base ligand is used. $\mathrm{EtOH} \cdot \mathrm{H}_{2} \mathrm{O}$ and DMF. $\mathrm{H}_{2} \mathrm{O}$ were used as solvents and $\mathrm{pH}$ was in the range of weak acid. Interfering cations such as $\mathrm{Fe}(\mathrm{II})$. In(II), Ga(II). $\mathrm{Be}(\Pi)$ and $\mathrm{Cu}(\square)$ and interfering anion such as $\mathrm{F}^{-}$were employed. Many interfering ions in Table 2 were also employed when using Superchrome Garnet $\mathrm{Y}^{2}$ Pontachrome Blue Black R. ${ }^{21}$ Eriochrom red B, ${ }^{2 \geq}$ Morin. ${ }^{23}$ lumogallion. ${ }^{24}$ 8-hy drostquinoline-5-sulfoinic acid.

AI(II) Analysis in Natural Water. A fluorometric method using Schiff base ligand was very satisfactory when applied to the quantitative analysis of $\mathrm{Al}(\mathrm{II})$ in the natural water samples. Natural water samples were obtained from various sources such as tap water. river water. spa water. sea water and waste water. Quantitative analysis of $\mathrm{Al}(\mathrm{III})$ ion content was performed through AAS. standard addition and calibration curve method

Table 3 compares the results obtained by calibration curve method with standard addition method (AAS method is taken as standard). Error value of Al(II) quantitative analysis was more than $96.2 \%$. It is almost the same to the error value previously calculated. $6,7,9$

In conclusion. a novel Schiff base ligand 5-methoxy-2pheny liminomethỵlphenol (5- $\mathrm{CH}_{3} \mathrm{O}$-PMP) was sy'nthesized and fluorometric method was developed for the quantitative analysis of $\mathrm{Al}(\mathrm{II})$ ion in various water samples up to 0.27 $\mathrm{ng} / \mathrm{mL}$

Acknowledgments. The authors thank office of international affairs of Daegu University for the proofreading. This research was supported in part by the Daegu University Research Grant, 2007.

\section{References}

I. Wong, M. H.; Fung, K. F.; Carr, H. P. Toxicalogv Lenters 2003 , 137, 111

2. Scancar, T.; Stibili, V.; Milacic, S. R. Food Chem. 2004, 85, 151.
3. Coscion, A. R.: Andrade, J. C.: Poppi, R. J.: Mell, C.: Raij, B.; Abrell, M. F. Anal Chim .tcta 2000, 423, 31 .

4. Chundak, S. Y.; Sukharev, S. N. J. Anal. Chem 1997, 52(6), 542 .

5. Donaldson, E. M. Talanta 1971, 18, 905

6. Kim, S. D.; Lee, D. H.; Kim, J. S. Bull. Kor. Chen. Soc. 2008, $297(1), 245$.

7. Capitan, F: Avidad, R: Navalon, A: Capitan-Vallvey, L. F. Hakrochim. Acta 1992,107,65.

8. White, C. E: McFarlane, H. C. E: Fogt, T: Fucks, R. Anal. Chem. 1967, 39(3), 367.

9. Gomez Ariza, T. L:: Marques Gonzalez, M. L.: Montana Gonzalez, M. T. Analust 1984, 109, 885

10. Cannopavon, I. M.: Trujillo, M. L.; Garcia de Torres, A. Anal. Chim. Acta 1980. 123.31

11. (a) Morisige, K. Anal Chim tcta 1980, 121, 301. (b) Morisige, K. Anal Chim .Acta 1974, 295, 319. (c) Morisige, K. Ihorg. Bitcl. Chem. 1978, to, 843.

12. Gupta, V. K: Goval, R. N.; Tain, A. K.; Shama, R. A. Elec: Chim. Acta 2008, 10, 1016 .

13. Gholivand, M. B.; Ahmadi, F.; Rafiee, E. Electrontalysis 2006, 16,1620 .

14. Abbaspour, A.; Esmaeilbeig, A. R.; Tarrahpour, A. A.; Khajeh, B.: Kiá, R. Talanta 2002, 58, 397.

15. Standard methods for the examination of water and wastewater. $19^{\text {dh }}$ Ed: APHA: Washington. DC. 1995: pp 1-22 1-24.

16. Argaller, R. J.: White, C. E. Anal Chem 1964, 36(11), 2141

17. Morisige, K. J. Ihorg. Nucl Chem 1978, 40,843.

18. Skoog, D. A.: Holler, E. T.: Crouch, S. R. Principles of Instrimental Analvsis, $6^{\mathrm{d1}}$ ed.; Tomson Brooks/Cole: 2007; Chapter 15.

19. Valeur B. Holecular Fltorescence Principles and Application: Wiley-VCH: Weirheim, New York, 2005; Chapter 3.

20. Hiraki, K. Bull. Chem. Soc. Japan 1972, 45, 1395

21. Weissler, A.; White, C. E. Ind. Eng. Chem. Anal. Ed. 1946, $18(9), 530$

22. Carrillo. F.: Perez. C.: Camara. C. Anal Chim. Acta 1991. 243. 121

23. (a) Will II. F. Anal Chem 1961.33(10), 1360. (b) White, C. E.: Lowe, C. S. Ind. Eng. Chem. Anal. Ed. 1940, 12(4), 229

24. (a) Zhang. J.: Xu. H.: Ren. J. L. Anal Chim. Acta 2000, 405.31 (b) Howard, A. G.; Coshead, A. I.; Potter, I. A.; Watt, A. P. Analvst 1986, 111, 1379. (c) Hydes, D. T. Liss, P. S. Analvst $1978,101,922$

25. Kawakubo, S.; Yamamoto, S.; Iwatsuki, M.; Fukasawa, T. Bunseki Kagaku 1992, 11,65 . 